\title{
INDEPENDENSI DAN IMPARTIALITAS HAKIM PERSPEKTIF TEORITIK - PRAKTIK SISTEM PERADILAN PIDANA ${ }^{1}$
}

\author{
Oleh :
}

\author{
I Gede Winartha Indra Bhawana ${ }^{2}$
}

\begin{abstract}
Funcioning judicial institutions to ecamine and decinde the defendant in a criminal case by a judge who is authorized by the distributive law: The judge has the authority to decide upon the independence and impartiality by anyone. The judge in the funciton of enforcing the law aimed at justice, the ralization of benefits to all parties, as well as legal certaintly. In the criminal justice process procedurally and factually do not work alone, the process of criminal justice mechanisme worked otu by other law enforcement agencies such as investigators, prosecutors, correctional supervisors by advocates as a companion and seeking justice. Indonesia criminal justice partterned integrally in the same purpose of comating crime. A fair legal process the expections and objectives in law enforcement, free from judicial mafia practices, with supported independence, feedom an impartiality of judges in deciding. An issues of the judiciary through its justices already act according to the correct theory of the judicial system and the ideal ? and make decisions? the oretically will be answered through the legal conclusions that sometimes judges indeciding upon th eusbjective and tend to ignore the principles of the scienteifc theory of the criminal justice system, and tends to bring the mission of freedom without limits.
\end{abstract}

Keywords : Independce and Impartiality, Judges, Criminal Justice System

\begin{abstract}
Abstrak
Lembaga pengadilan berfungsi memeriksa dan memutus terdakwa dalam perkara pidana melalui hakim yang diberi kewenangan atributif oleh undang-undang. Hakim dalam memutus memiliki otoritas kemandirian dan ketidakberpihakan oleh siapapun. Hakim dalam fungsi menegakkan hukum bertujuan tegaknya keadilan, terwujudnya kemanfaatan bagi semua pihak, serta adanya kepastian hukum. Dalam proses peradilan pidana secara prosedural dan faktual tidak berfungsi sendirian, proses mekanisme peradilan pidana dikerjakan oleh penegak hukum lain seperti penyidik, penuntut, pembina oleh pemasyarakatan dan advokat selaku pendamping pencari keadilan. Peradilan pidana Indonesia berpola secara terpadu dalam tujuan sama untuk memerangi kejahatan. Proses hukum yang adil menjadi harapan dan sasaran dalam penegakan hukum, terbebas dari mafia praktek peradilan, dengan ditunjang kemandirian, kebebasan dan kenetralan hakim dalam memutus. Menjadi masalah lembaga peradilan melalui hakimnya sudahkah berperan sesuai teori sistem peradilan yang benar dan ideal ? Serta adakah batas-batas kebebasan bagi hakim dalam mengambil putusan ? Secara

Artikel ini merupakan karya ilmiah mahasiswa pada Program Studi Magister S2 lmu Hukum Program Pascasarjana Universitas Udayana dan mengucapkan terima kasih kepada para reviewer

2 Penulis adalah Mahasiswa Magister Ilmu Hukum Universitas Udayana Denpasar, Bali. Alamat : Perum. Taman Mahayu II No. 18 Sempidi, Badung, Email : winarthaindra10@ gmail.com
\end{abstract}


teoritik akan terjawab melalui penelitian normatif hukum lewat tulisan karya ilmiah ini, yang pada simpulan awal bahwa terkadang hakim dalam memutus cenderung subyektif dan mengabaikan prinsip-prinsip teori keilmuan sistem peradilan pidana, serta cenderung membawa misi kebebasan tanpa batas.

Kata Kunci : Independensi dan Impartiabilitas, Hakim, Vonis

\section{PENDAHULUAN}

\subsection{Latar Belakang}

\section{Sudah menjadi}

anggapan

umum bagi orang awam hukum bahwa benteng terakhir diperolehnya keadilan oleh para pencari keadiian (justisiabel) adalah terletak di ruang sidang pengadilan, melalui tangantangan hakim dengan ketokan palunya yang ampuh guna menentukan nasib seorang terdakwa, apakah akan diputus bebas (vrinjspraak), lepas (ontslaag) ataukah dipidana (veroordeling)

Namun nasib terdakwa tidak bisa ditentukan sendiri oleh hakim (pengadilan) sehingga setiap pencari keadiian tidak secara sepenuhnya memperoleh apa yang diharapkan hanya dari sebuah putusan hakim atau pengadilan. Beberapa rangkaian proses hukum awal harus dilalui mulai dari kepolisian dan kejaksaan barulah tiba akhirnya proses akan dilaksanakan oleh pengadilan, dan masih ada rangkaian proses selanjutnya seperti dijalaninya sanksi oleh terpidana di Lembaga Pemasyarakatan, dalam dunia teori peradilan dikenal dengan sebutan sistem peradilan pidana. (criminal justice system)

Sub-sub unsur dalam law
inforcement yang dalam hal
penegakannya berbicara institusi /
kelembagaan akan melibatkan Polisi,

Penuntut Umum, Hakim dan Sipir dan Penasihat Hukum selaku stage older dari terselenggaranya penegakan hukum terpadu. Semuakomponen yang terlibat tadi harus bekerja sebagai suatu sistem secara timbal balik, isi mengisi dan tidak terlepas satu dengan yang lainnya. Mereka tidak akan berhasil mengemban misinya bila bekerja secara sendiri-sendiri, hal ini seperti apa yang digambarkan oleh Kenneth J. Peak dengan awal pertanyaannya secara berangkai berupa hal-hal sebagai berikut :

What is it the justice administration?

- Police, court, and correction administrator?

Actually administer? Obviosly, these administrator do not provide leadership over a system that has succeeded in accomplishing its mission. But do individuals within the system work amiably and communicate well with one another? ${ }^{3}$

Penyelenggaraan pelaksanaan proses peradilan pidana dengan tujuan penegakan proses peradilan yang mencerminkan keadilan (due process of law) harus dilakukan

\footnotetext{
Kenneth J. Peak, 1995, Justice Administration, Police Courts, and Connections Management Department of Criminal Justice, University of Nevada, Reno, PHE New Jersy, p.5.
} 
dengan tujuan serta arah yang sama dari tiap-tiap komponen sub sistem (institusi tadi). Ketidak kompakan tujuan akan menimbulkan kinerja sistem yang tidak sempurna dan bermuara kepada pelecehan-pelecehan hukum yang melahirkan fenomenafenomena seperti ketiadaan keadilan (absence of justice) pengabaian akan hukum (disregarding the law), ketidakhormatan pada hukum (disrespecting the law), ketidak percayaan pada hukum (distrusting the law) dan dalam beberapa hal penyalahgunaan hukum (misuse of the law) ${ }^{4}$.

Untuk kondisi Indonesia fenomena pelecehan-pelecehan akan hukum seperti di atas akan menimbulkan gejala seperti tindakan main hakim sendiri oleh masyarakat (eigenrechting), tindakan masyarakat berupa pelecehan terhadap pengadilan (contemptof court) secara fisik merusak gedung pengadilan, melempar hakim dengan sepatu, mencaci hakim dan sebagainya.

Semua ini dilakukan oleh pencari keadilan berkat harapan mereka tidak tercapai seperti ketiadaan kepastian hukum, ketiadaan keadilan akan putusan (hakim) serta manfaat proses yang mereka (justisiabel) jalani kurang bahkan tidak dirasakan membawa manfaat. Atau dalam bahasa teoritik sebagai akibat maraknya terjadinya

4 Harkristuti Harkrisnowo, 2002, Sistem Peradilan Pidana Terpadu (Integral Criminal Justice System) Sebuah Perspektif, News Letter, KHN, Jakarta, hlm. 10. mafia praktek peradilan dalam proses peradilan.

Beban terberat yang selalu ditimpakan oleh pencari keadilan selalu ditujukan kepada pengadilan (dalam hal

ini hakim), padahal untuk lahirnya sebuah harapan berupa putusan yang adil dan tidak memihak dilahirkan oleh sebuah proses suatu sistem yang ditunjang oleh kinerja sub-sub sistem (secara institusi) seperti Kepolisian, Kejaksaan, Pengadilan, Lembaga Pemasyarakatan, Pengacara (advocat) serta komponen masyarakat itu sendiri ${ }^{5}$.

Keharusan bekerjanya suatu sistem secara utuh dalam sistem peradilan pidana sehingga menghasilkan out put (keluaran) atau arah tujuan penegakan hukum yang adil (due process of law) secara ideal harus mengandung elemen-elemen seperti berikut:

a. Rulification to facilitate standard and equal treatment of smiliar situations, thus written rules and necessary as a legal basis of actions conducted by those agencies functioning within the system.

b. Functional diffrentation to ensure a specific sphere of competence of each agency within the system, so as to :

\footnotetext{
Artha, I Gede, 2012, Kebijakan Formulatif Upaya Hukum Terhadap Putusan Bebas Bagi Penuntut Umum Dalam Perspektif Sistem Peradilan Pidana Indonesia (Disertasi), Unibraw, Malang, hlm. 112.
} 
- Prevent overlapping authority.

- Clarify the respqnsibility of each

$$
\text { agency }
$$

c. Coordination among units to ensure that each agency supports the other in order to achieve the objective of the system

d. Expertise drived from special training for each agency

e. Control mechanism to make a sure that each agency and the whole system functions properly. ${ }^{6}$

Sejalan dengan harapan Kenneth J. Peak tadi, fungsi yang seharusnya dijalankan oleh sistem peradilan pidana (terpadu-Indonesia) seperti dipaparkan oleh Harkristuti Harkrisnowo mengharuskan adanya harapan-harapan penulis sarikan berupa :

a. Melindungi masyarakat melalui upaya penanganan dan pencegahan kejahatan, merehabilitasi

pelaku kejahatan dan melakukan upaya inkapasitasi terhadap orang yang merupakan ancaman terhadap masyarakat.

b. Menegakkan dan memajukan the rule of law dan penghormatan pada hukum dengan menjamin adanyadue process dan perlakuan yang wajar bagi tersangka, terdakwa dan terpidana, melakukan penuntutan dan membebaskan orang yang tidak bersalah yang dituduh melakukan kejahatan.

c. Menjaga hukum dan ketertiban.

d. Menghukum pelaku kejahatan sesuai dengan falsafah pemidanaan yang dianut membantu dan memberi nasihat pada korban kejahatan ${ }^{7}$.

Mengacu pada komponenkomponen sub sistem masing-masing yang ada baik dari kepolisian, kejaksaan, pengadilan, Lembaga Pemasyarakatan serta peran pengacara, sudah semes-tinya sub-sub sistem (institusi) ini memperhatikan ramburambu seperti yang digariskan oleh Kenneth J. Peak tersebut di atas seperti keharusan akan adanya standar fasilitas yang memadai seperti aturan dasar hukum, tidak adanya ketumpang tindihan tugas dan kewenangan, adanya koordinasi diantara sesama sub sistem (institusi), adanya pelatihan yang cukup bagi pengendali sistem yang ada, kemudian adanya mekanisme pengawasan terhadap pengendali fungsi dari sistem yang ada.

\subsection{Perumusan Masalah.}

Sehubungan dengan keharusan yang dituntut secara normatif ideal di atas dihubungkan dengan sistem peradilan pidana Indonesia yang semenjak diberlakukannya KUHAP (UU No. 8 Tahun 1981) sejak 31 Desember 1981 menyatakan diri menganut dan menerapkan pola penegakan hukum terintegrasi

\footnotetext{
Harkristuti Harkrisnowo, Op Cit, hlm. 12.
} 
dalam memberantas kejahatan, kalau dipandang perspektif teori dan prakteknya tampak berbagai kendala yang dapat diidentifikasi rumusan masalahnya seperti berikut.

1. Apakah lembaga peradilan sudah menjalankan perannya sesuai idealisme sistem peradilan pidana?

2. Apakah ada batas-batas kebebasan yang dimiliki oleh lembaga peradilan?

Demikian 2 (dua) butir permasalahan yang perlu ditelusuri dari aspek teoritik dan praktek bekerjanya sistem peradilan pidana (criminal justice system).

\section{METODE PENELITIAN}

\subsection{Jenis Penelitian}

Karya ilmiah ini tergolong kedalam jenis penelitian hukum normatif atau penelitian hukum kepustakaan, karena penelitian hukum ini dilakukan dengan cara meneliti bahan kepustakaan (library research) yang terdiri dari bahan hukum primer dan ditunjang oleh bahan hukum sekunder.

Menurut Soerjono Soekanto dan Sri Mamudji, penelitian hukum normatif atau kepustakaan tersebut terdiri dari :

1. Penelitian terhadap asas-asas hukum secara teori.

2. Penelitian terhadap sistematik hukum secara teoritis

3. Penelitian terhadap sinkronisasi vertikal dan horisontal dari suatu undang-undang
4. Perbandingan hukum beberapa negara

5. Sejarah hukum dari suatu negara ${ }^{8}$.

Sehubungan dengan klasifikasi tersebut diatas maka penelitian hukum normatif ini menyangkut penelitian taraf sinkronisasi vertikal atas disharmonisasi norma yang ada beberapa perundang-undangan pidana. Suatu peraturan perundangundangan yang tergolong dalam bahan hukum primer. Dengan meneliti beberapa undang-undang seperti Undang-undang No. 8 Tahun 1981 (KUHAP), Undang-undang No. 48. Tahun 2009 (Undang-undang Kekuasaan Kehakiman), Undang.undang No. 3 Tahun 2009 (Undangundang Mahkamah Agung), dan Undang-undang No. 49 / 2009 tentang Peradilan Umum. Undang Undang Nomor 16 Tahun 2004 tentang Kejaksaan Undang - Undang Nomor 18 Tahun 2003 tentang Advokat dan Undang - Undang Nomor 12 Tahun 1995 tentang Pemasyarakatan.

\subsection{Metode Pendekatan}

Sesuai dengan karakteristik dan sifat penelitian normatif (kepustakaan), maka dalam penelitian ini akan memakai beberapa metode pendekatan, diantaranya:

- $\quad$ The Statue Approach pendekatan perundang-undangan.

\footnotetext{
Soerjono Soekanto, Sri Mamudji, 2001, Penelitian Hukum Normatif, PT. Raja Grafindo Persada, Jakarta, hlm. 7.
} 
- The Analitical and Conseptual Approach (pendekatan analisis konsep hukum).

- The Case Approach atau Pendekatan Kasus.

- $\quad$ The Comparative Approach atau Pendekatan Perbandingan.

- Philosophical Approach atau Pendekatan Kefilsafatan, yaitu:

a. Ontologi hukum

b. Aksiologi hukum

c. Epistemologi hukum

d. Teologi hukum

e. Ideologi hukum

f. Logika hukum

g. Keilmuan hukum ${ }^{9}$.

\subsection{Sumber Bahan Hukum}

Penelitian hukum bersifat norma-tif, maka jenis bahan hukum yang lazim dipergunakan adalah :

a. Bahan-bahan Hukum Primer

b. Bahan-bahan hukum sekunder.

c. Bahan-bahan hukum tersier ${ }^{10}$

Sehubungan dengan penelitian hukum normatif karya tulis ilmiah memakai sumber bahan hukum dari :

1. Bahan hukum sekunder, yakni memberikan penjelasan mengenai bahan hukum primer.

2. Bahan hukum tersier, dalam hubungan penelitian ini menyangkut seperti kamus atau ensiklopedi.

\footnotetext{
Ronny Hanitijo Soemantri, 1989, Metode Penelitian Hukum dan Jurimetri, Ghalia Indonesia, Jakarta, hlm. 11 - 12.

$10 \quad$ Ibid, hlm. 13.
}

\subsection{Metode Pengumpulan Bahan Hukum}

Penelitianiniuntukpengumpulan bahan hukum memakai metode sistematis, yakni berupa pengumpulan bahan peraruran perundang-undangan.

\subsection{Teknik Analisis Bahan Hukum \\ Menggunakan teknis analitis seperti : \\ - $\quad$ Teknik diskripsi \\ - $\quad$ Teknik interpretasi \\ - $\quad$ Teknik evaluasi \\ - $\quad$ Teknik argumentasi \\ - $\quad$ Teknik sistematisasi \\ - $\quad$ Metode konstruksi hukum ${ }^{11}$.}

III. HASIL DAN PEMBAHASAN

3.1. Eksistensi Sistem Peradilan Pidana (Criminal Justice System) dari Segi Teoritik

Menurut teorinya Kenneth J. Peak bekerjanya sistem peradilan pidana (criminal justice system) akan menampakkan dirinya/berfungsi sebagai:

a. A true system of justice

b. A criminal justice process

c. A criminal justice network

d. A criminal justice nonsystem ${ }^{12}$

Sistem peradilan pidana dalam fungsi/perannya sebagai $A$ true system of justice semestinya menampakkan diri dengan ciri keberadaan adanya hal-hal :

Ibid, hlm. 14.

12 Kenneth J. Peak, Op Cit, hlm. 5 - 7. 
- Adanya ketentuan/landasan hukum sesuai prosedural yang tegas, sebagai acuan dan rambu-rambu untuk bertindak dari para pelaksana penyelenggaraan peradilan.

- Adanya pembedaan fungsi/ peran akan tugas dari masing-masing komponen penyelenggara (tidak ada difrensiasi fungsional).

- Adanya koordinasi antar lembaga yang baik.

- Keahlian yang dimiliki tiap-tiap fungsionalisasi sesuai dengan bidang yang diemban.

- Adanya mekanisme kontrol internal dan eksternal, vertikal dan horizontal yang tegas.

Sistem peradilan pidana sebagai

A criminal justice process, dengan ciri-ciri seperti:

- Mengutamakan pencapaian target kerja sesuai bidangnya masing-masing, dengan terikat dan mengacu pada ketentuan fomalitas.

- Tujuan dari masing-masing komponen penyelenggara administrasi peradilan samasama berbeda.

- Kinerjanya cenderung tampak seperti operasional yang pragmentaris, bukan menunjukkan kinerja dalam arti ideal.

Penegakan hukum (criminal justice system) sebagai criminal justice network, menampakkan ciri dengan fungsi seperti:

- Para administrator penyeleng-gara peradilan terikat sebatas melaksanakan jaringan kerja, dengan tujuan yang tidak sama, jaringan kerja yang diciptakan tidak terangkai sebagai suatu sistem.

- Masing-masing dari penyeleng-gara komponen sistem (dari tiap institusi) memiliki kewenangan diskresi berlebihan/tanpa batas yang jelas.

- Tidak adanya sanksi yang jelas dan tegas bila administrator salah/ menyimpang menjalankan fungsinya.

Sistemperadilanpidana(criminal justice system) sebagai suatu A criminal justice nonsystem, dengan ciri-ciri seperti berikut:

- Merupakan lawan dari ciri yang terkandung dalam true system seperti ketentuan prosedural tidak tegas, adanya difrensiasi fungsional fungsionalisasi administrator peradilan.

- Tidak adanya koordinasi yang baik antar lembaga.

- Kurang memiliki dan menguasai keahlian dimasing-masing yang menjadi bidang tugas dan perannya. 
- Kurangnya mekanisme kontrol terhadap kinerja masing-masing baik internaleksternal maupun vertikalhorizontal.

\subsection{Sistem Peradilan Pidana Amerika Serikat}

Dengan berpedoman kepada hal-hal di atas sebagai pola-pola mekanisme kerja sistem peradilan pidana (criminal justice system/CIS) maka perlu meninjau sepintas sistem peradilan pidana (CJS) di Amerika Serikat.

Di Amerika Serikat tampak pula peran CJS belum menunjukkan sebagai suatu sistem yang benar ( $a$ true criminal of justice) hal ini tampak dari adanya pernyataan-pernyataan dari Kenneth J. Peak, dapat disarikan penulis :

- $\quad$ "Each system component-police, court and corrections varying degrees of responsibility and discreation for dealing with crime .... each system component to engage.... areoftencharacterized by friction, conflict, and dificient communication.

- $\quad$ Procecutors is the poor quality of case report they receive from the police.

- $\quad$ The court are more independent in their operation, largely sentencing offenders as they fit.

- Corrections agencies or torn between the philosophies of punishment and rehabilitations

- Menurut hasil penelitian di Amerika kinerja CJS menampakkan pula peran seperti criminal justice nonsystem, hal ini tercermin dalam pernyataan Peak, "The maintain that the three segments of the system used in the United States to deal with criminal behavior do not always function in harmony."

Hal di atas diperkuat oleh pernyataan Alfred Cohn and Roy Udolf bahwa CJS di Amerika "is not a system, and it has little to do with justice as that term is ordinarily understood."

- Bahwa component system di Amerika seperti polisi, pengadilan dan Lembaga Pemasyarakatan (police, court and corrections components work and interact such as to functions like a "process, network", or even nonsystem.

Menurut J.W. La Patra, menilai pendapat Kenneth J. Peak bahwa memang di Amerika CJS tampak ada namun fungsinya masih minim, seperti dinyatakan "that criminal justice system doest exist, but that it functions very poorly. The CJS is a loosely connected, nonharmonious.

Jadi sistem peradilan pidana Amerika Serikat belum pula terpola sebagai suatu sistem yang utuh ( $a$ true criminal justice system) karena diantaranya diwarnai oleh adanya kewenangan deskresi yang bebas dimiliki oleh tiap administrator 
peradilan terutamanya pengadilannya, disamping kinerja komponen sub sistem institusi tidak menunjukkan adanya interconected sesama mereka.

\subsection{Sistem Peradilan Pidana Indonesia (Integrated Criminal Justice System) Sistem Peradilan Pidana Terpadu}

Semenjak diberlakukan UUNo. 8 Tahun 1981 tanggal31 Desember 1981, Indonesia mengklaim diri menyatakan menerapkan sistem peradilan pidana terpadu di dalam usaha menegakkan proses hukum (pidana) atau penegakan hukum untuk menuju proses yang adil, jujur tanpa memihak. Menyimak dari adanya kata "sistem", dan "terpadu" tersebut akan banyak menimbulkan permasalahan hukum, seperti : sudahkah penyelenggaraan peradilan pidana Indonesia masuk dalam peran arti sistem yang sebenarnya (a true criminal justice system) ? Dan pula arti kata terpadu sebatas apa dan bagaimana yang dimaksud.

Kalau diteliti dan dicermati KUHAP dalam hubungannya di atas (dalam arti CJS) akan tampak hal-hal yang menggambarkan pola penegakan hukum terkorelasi (Indonesia) / Integrated criminal justice system seperti karakteristik sebagai berikut:

Integrated CJS di Indonesia cenderung tampak berpola sebagai A criminal justice network, menunjukkan adanya sebatas hubungan kerja (inter conneksi antara sesama penegak hukum (polisi, jaksa, hakim,
Lembaga Pemasyarakatan dan pengacara), kelalaian atau penyimpangan tugas atas tanggung jawab yang semestinya diemban oleh komponen institusi tidak disertai adanya sanksi.

Misalnya contoh dalam terjadinya proses prapenuntutan Pasal 138 ayat (1), (2) KUHAP, dalam upaya praperadilan Pasal 77 KUHAP) kekeliruan aparat seperti penyidik/ penuntut umum dalam melaksanakan tugasnya tidak ada sanksi (pidananya), hanya berupa pemulihan sanksi ganti rugi oleh negara dan atau rehabilitasi nama baik korban.

- Kewenangan diskresi dari masing-masing aparat penegak hukum sangat luas seperti kepolisian,jaksa, hakimmemiliki kewenangan melakukan penangguhan penahanan tanpa kejelasan, alasan dan dasar yang formal, menghentikan penyidikan, penghentian penuntutan, pendeponiran perkara, serta hakim/pengadilan memiliki kebebasan (kemerdekaan) yang demikian besar di Indonesia sesuai esensi Pasal 1 Legislasi Bidang Kehakiman, hal ini menunjukkandiskresipengadilan sangat luas seperti adanya rentangan ketentuan panjang terhadap penjatuhan pidana hilang kemerdekaan dengan minimum 1 hari maksimum 15 tahun penjara atau sampai 20 tahun. Sehingga dari' deskresi 
ini akan menimbulkan adanya desparitas putusan hakim yang mengundang opini publik pro dan kontra.

- Kata "terpadu" akan berbeda dengan pengertian sistem(CJS as true a system), karena bekerjanya sistem di Indonesia dalam arti baru sebatas mekanisme dari institusi (polisi, jaksa, hakim) belum didukung oleh komponen sistem yang lain seperti perangkat hukumnya, integritas koordinasi serta kontrol intern-ekstern, vertikal-horizontal.

- $\quad$ Keyakinan (hakim) faktor utama sebagai penentu pertimbangan putusan untuk memidana sesuai esensi Pasal 183 KUHAP, disamping didukung oleh minimal dua alat bukti yang sah (disini tampak subyektivitas hakim yang menonjol).

\subsection{Bentuk/Model Pemeriksa-an Kriminal}

Dalam proses penegakan hukum yang berkeadilan secara idealisnya dikenal dua model pemeriksaan (due process of law) yang oleh Herbert L. Packer dibagi menjadi dua:

- Due process model (DPM)

- Crime control model (CCM)

Two models of the criminal process will let us perceive the normative antimony at the heart of the criminal law $w^{13}$

\footnotetext{
13 Herbert L. Packer, 1968, The Limits of The Criminal Sanction, Stanford.
}

Kedua bentuk/model dalam pemeriksaan proses kriminal di atas demikian pentingnya memberikan corak yang agak berbeda namun tujuannya adalah sama memberikan perlindungan terhadap hak asasi seorang tertuduh atas landasan klausula due process of law.

Ada pula ilmuwan Mirjan Damaska lain memberi istilah model pemeriksaan di atas dengan sebutan:

- Advesary system yang sama dengan accusatorial system, dan non advesary system yang sama dengan inquisitorial system.

Kedua model di atas berlaku pula di Amerika Serikat.

Ciri atau Karakteristik Due Process Model (DPM)

Di dalam proses hukum yang berkeadilan dengan memakai pola DPM ini yang dominan tampak adalah sasaran-sasaran seperti berikut:

- $\quad$ Sasaran yang diutamakan dengan menegakkan asas persamaan di muka hukum dengan menjunjung tinggi hak-hak asasi manusia dan menempatkan serta menerapkan asas presumption of innosence.

- Pemeriksaan dilakukan secara terbuka.

- Pemeriksaan terhadap tersangka/ terdakwa baru dilakukan bila sudah memperoleh hak penuh untuk dibela pengacara.

Menerapkan proses pemeriksaan secara bertahap (due process model looks very much like an obstacle course). Jadi peran 
pengacara/advocat sangat besar tampak memegang peranan yang penting.

- $\quad$ Tujuan model ini secara khusus untuk melindungi bagi mereka yang factual tidak bersalah (factualy innosence), dan atau menuntut mereka yang factual bersalah (factualy-guilt).

- Mengutamakan kesusilaan dan kegunaan sanksi pidana (criminal sunction).

- $\quad$ Model(DPM) ini disebut sebagai suatu negatif model karena menegaskan sangat perlunya pembatasan atas kekuasaan dan cara penggunaan kekuasaan oleh aparat penegak hukum.

- Ciri atau Karakteristik dari Crime Control Model (CCM)

Adapun warna yang khas dalam model pemeriksaan proses kriminal (CJS) pada CCM ini tampak hal-hal berikut seperti :

- Tersangka/terdakwa dianggap telah bersalah sebelum menjalani pemeriksaan dengan buktibukti diperoleh secara akurat (menerapkan asas presumption of guilt atau praduga bersalah), hal ini dilakukan demi efisiensi dari penegakan hukum.

- Proses pemeriksaan dilakukan secara cepat (speedy) dan tuntas (penalty).

- $\quad$ Peran pengacara/advocat sangat terbatas.

- $\quad$ Tindakan represif terhadap suatu tindakan kriminal merupakan fungsi terpenting dari suatu proses peradilan.
- $\mathrm{CCM}$ menerapkan pola pemeriksaan secara langsung (umum) - CCM resemblesan assembly line.

- $\quad$ CCM menekankan pada bentuk penggunaan kekuasaan formal, yang oleh HL Packer bentuk CCM ini disebutnya dengan istilah Affirmative Model ${ }^{14}$.

Bagi Indonesia kedua model pemeriksaan kriminal di atas dapat dijelaskan seperti berikut, secara historis sebelum berlakunya UndangUndang No. 8 Tahun 1981 (KUHAP), dimana masih berlaku hukum acara pidana atas landasan HIR (Herziene Inlandsh Reglement) Stb : Nomor 44 Tahun 1941.

Namun dalam perkembangan politik hukum selanjutnya di Indonesia, setelah diberlakukannya KUHAP sejak tanggal 31 Desember 1981, arah penegakan hukum khususnya di bidang hukum pidana terutama menyangkut pola pemeriksaan proses kriminal sudah menuju pada pola Due Process Model (DPM) ini sebagai tuntutan seperti apa yang telah dicanangkan dalam berbagai pasalpasal KUHAP yang mengakomodir hak-hak tersangka/terdakwa dalam menjalani proses peradilan pidana dengan menuju kepada perlindungan akan martabat hak-hak asasi manusia, bila seseorang terlibat berhadapan dengan hukum.

$14 \quad$ Ibid, hlm. 173. 
Usaha perlindungan ke arah persamaan tiap orang dimata hukum tampak dalam KUHAP seperti:

- Penghormatan setiap orang dalam wujud penegakan asas presumption of innosence (penjelasan umum KUHAP angka 1 butir c) jo Pasal 8 Undang-Undang Pokok Kekuasaan Kehakiman Republik Indonesia No. 48 Tahun 2009.

- Asas pemberian bantuan hukum dalam semua tingkat proses peradilan (huruf $f$ penjelasan) jo Pasal 54 KUHAP).

- Tersangka/terdakwa dipandang sebagai subyek (hukum) yang sejajar kedudukannya dihadapan pemeriksaan disemua tingkatan proses peradilan (asas equality before the law, Pasal 5 KUHAP).

- $\quad$ Pemeriksaan yang terbuka untuk umum.

- Sesuai dengan tujuan dan misi hukum pidana formal, kebenaran yang dicari adalah kebenaran materiil atau kebenaran yang hakiki.

Akan tampak berbeda saat diterapkannya HIR Stb. No. 44 Tahun 1941 pola pemeriksaan yang diterapkan dalam proses pemeriksaan kriminal tampak dominan memakai pola CCM (Crime Control Model), karena pada waktu itu warna pemeriksaan terhadap tersangka/terdakwanya bercirikan hal-hal seperti:

- Tersangka/terdakwanya dipandang sebagai obyek pemeriksaan, yang dikejar hanya pengakuan (formal) yang sifatnya semu.

- Kedudukan tersangka/terdakwa dengan pemeriksa tidak sejajar.

Kecenderungan mengabaikan alat-alat bukti sebagai pedoman. Peranan advocat/pengacara sangat terbatas (baru bisa didampingi setelah di persidangan).

Hak-hak tersangka/terdakwa sering terabaikan.

- Perlindungan hukum akan martabat tersangka/terdakwa sangat kecil, seperti penahanan tanpa batas waktu yang jelas, penangkapan secara semenamena dan sebagainya.

Pada saat pemberlakuan HIR itu dikenal dengan istilah menerapkan sistem pemeriksaan secara inquissitoir (tersangka / terdakwa dipandang sebagai obyek), yang oleh Mirjan Damaska (Dalam Romli Atmasasmita) sistem inqussitoir ini disebutnya advisary inuisitorial system $^{15}$

Dengan mencermati praktek penegakan hukum di Indonesia selama ini (terutama setelah berlakunya KUHAP), model pemeriksaan proses kriminal (CIS) belum mengarah sepenuhnya menerapkan pola pemeriksaan DPM (Due Process Model), bahkan dalam prakteknya masih banyak diterapkannya pola-pola

15 Romli Atmasasmita, 1996, Peradilan Pidana PerspektifEksistensialisme dan Abolisionisme, (Dalam Mirjan Damaska), Bina Cipta, Bandung, hlm. 108. 
CCM (Crime Control Model), seperti halnya masih sering diabaikannya/ dilanggarnya asas presumption of innosence oleh penyelenggara pelaksanaan peradilan (administrator of justice), pemberian bantuan hukum struktural tidak optimal, perlakuan terhadap tersangka/terdakwa yang sering diskriminatif, desparitas putusan hakim yang mengundang pro dan kontra, semua fenomena dan gejala hukum di atas, sebagai ciri penerapan pola pemeriksaan kriminal yang semestinya dengan sasaran Due Process of Law di Indonesia belum berjalan sesuai harapan teori (yang ideal) dan keinginan setiap pencari keadilan untuk mendapat perlakuan hukum yang adil, jujur dan tidak memihak atau putusan (hakim) yang bersari keadilan (penulis meminjam istilah dari almarhum pendekar hukum Ali Said, SH).

\subsection{Independensi, Peran dan Wewenang Pengadilan Dalam Sistem Peradilan Pidana (CJS)}

Sebagai salah satu komponen sub sistem dalam mekanisme proses penegakan peradilan pidana (criminal justice system) pengadilan adalah sebagai salah satu institusi penting tempat berprosesnya kasus dan malah penentu terakhir sebuah proses setelah tahap penyidikan (oleh kepolisian, penuntutan oleh kejaksaan) dan sesudahnya nanti masuk tahapan tugas Lembaga Pemasyarakatan.
Semua mekanisme pentahapan proses di atas tadi secara yuridis ilmiah diistilahkan dengan penyelenggaraan pelaksanaan peradilan atau administration of justice atau justice administration (dalam bukunya Kenneth J. Peak), dalam bukunya tersebut mengupas dan menguraikan peran dan wewenang Pengadilan (court) di Amerika Serikat.

Berbicara soal peran dan wewenang dari institusi pengadilan ini memang sangat luas, namun penulis disini akan mencoba secara sumir/sepintas melihat peran dan wewenang pengadilan dalam proses penegakan peradilan pidana di Amerika Serikat menyangkut isu hukum seperti : adanya kebebasan/ kemandirian Lembaga Peradilan (baik menyangkut kebebasan institusi / kelembagaan), maupun kemandirian yang dimiliki oleh personal (hakimhakimnya) dalam memerankan tugas dan kewenangannya yang diberikan oleh negara.

Kebebasan yang diberikan oleh negara melalui landasan perundangundangan sering diidentikkan dengan kewenangan diskresi.

- Independensi Pengadilan

Institusi pengadilan (melalui hakim-hakimnya) kiranya di negara manapun memiliki kewenangan yang bebas, merdeka, di negara maju sekalipun seperti Amerika Serikat kewenangan seperti itu bagi hakimhakim Amerika diakui eksistensinya, seperti pernyataan Kenneth J. Peak, "The court are more independent in 
their operation, largely sentencing offenders or they see fit,

Kebebasan, kemerdekaan adalah identik dengan sebutan diskresi akan menimbulkan problem jika kewenangan yang diberikan melampaui dan apa yang semestinya harus dilakukan sesuai aturan hukum yang telah mengaturnya. Idealnya control of Discretion (pembatasan akan tindakan diskresi seperti dikemukakan oleh Howard Abadinsky, three general methods will be applied in each of the parts of the criminal justice system under in subsequent :

1. Statutes / laws that see limits or parameters on discretion (e.q, minimum and maximum sentences beyond which a jude cannot reach.

2. Administrative rules that are promulgated by criminal justice agencies to limit the discretion of their employees (e.g, rules goverming the use of firearms by the police).

3. Supervisory controls/review whereby superior review the aktivities of lower ranking personnel to ensure uniformity and thus limit or control discretion (e.q. requiring an assistant proceentor to check with his/her suvervisor before agreeing to a plea bargain arrangement $)^{16}$

16 Abdinsky Howard, 1984, Discretionary Justice an Introduction to Discretion in Criminal Justice, Charles C. Thomas Publisher Spring Field - Illionis, USA, p. 10.
Selanjutnya Sue Titus Reid menyatakan betapa adanya peluang bagi pengadilan (hakim) dalam meluruskan ketidakadilan, seperti dikatakan, "An American Court has a higher capacity to rectify individual injustice

Gejala seperti ini dapat dicontohkan seperti dilukiskan oleh Benyamin Kaplan seorang Profesor di Harvard Law School bahwa di pengadilan pada tingkat pertama dengan menunjuk kepada kekuasaan terbatas dari hakim untuk menyisihkan keputusan dewan juri bilamana ia yakin bahwa keputusan itu jelas kurang wajar ... harus diperiksa ulang dihadapan hakim dan dewan juri lain ${ }^{17}$.

Disisi lain batas internaletikal dari kebebasan kekuasaan kehakiman diklarifikasi dengan menggunakan konsep "judicial self restrain (pengendalian diri hakim). Konsep ini dikenal luas di kalangan dunia peradilan di Amerika Serikat. Disana konsep ini dimaknai sebagai suatu "self emposed, discipline by judges in deciding cases without permiting themselves to indulge their own personel views or ideas ?."18

Demikian sekelumit gambaran akan kebebasan hakim (pengadilan) di Amerika Serikat dengan corak / warna

\footnotetext{
17 Sui Titus Reid, 1987, Criminal Justice Procedures and Issues, University of Tulsa, West Publishing Company, USA, hlm. 233

18 Benyamin Kaplan, 1996, Pemeriksaan Dengan Dewan Juri Ceramah -Ceramah Hukum Amerika, PT. Tata Nusa, Jakarta, hlm. 43.
} 
Anglosaxson yangjelas berbeda dengan pola yang dianut Indonesia sebagai konsekuensi bekas jajahan Belanda dengan corak Eropa kontinental (civil law).

Untuk ukuran Indonesia independensi dan impartialitas pengadilan (baca hakim) dijamin oleh ketentuan Pasal 1 Undang-Undang No. 48 Tahun 2009 tentang Kekuasaan Kehakiman, seperti lersurat :

"Kekuasaan kehakiman adalah kekuasaan negara yang merdeka untuk menyelenggarakan peradilan guna menegakkan hukum dan keadilan berdasarkan Pancasila demi terselenggaranya Negara Hukum Republik Indonesia.

Konteks praktek peradilan Indonesia arti kemerdekaan (bagi pengadilan/ hakim) sering disalahartikan dengan menafsirkan kewenangantanpabatasdanberlebihan, sehingga hakim (pengadilan) menerapkan kewenangan diskresinya yang berlebihan. Hal kondisi tadi didukung oleh adanya perangkat peraturan perundang-undangan baik menyangkut hukum pidana formalnya maupun hukum pidana materiilnya mengkondisikan seperti itu. Seperti contoh hakim dalam menjatuhkan pidana hilang kemerdekaan secara leluasa menurut keyakinan yang sifatnya subyektif (karena KUHP memasang rentangan minimum 1 hari hukuman penjara hingga maksimum 15 tahun penjara atau 20 tahun penjara). Kalau terpidana tidak puas atas suatu vonis ada upaya hukum baginya, hal ini sebagai dalih bagi hakim bahwa ia telah menjatuhkan putusan dengan kedok atas dasar undang-undang atau keyakinannya sendiri.

Semestinya kebebasan hakim di Indonesia jelas dibatasi oleh ketentuan undang-undang.Karena Indonesia sebagai negara yang mengklaim diri sebagai negara hukum dengan tipe rechstaat dan the rule of law.

Di dalam KUHAP kewenangan hakim yang tanpa batas ketentuan yang jelas seperti:

- Kewenangan hakim menolak/ mengabulkan penangguhan penahanan terdakwa.

- Pengalihan status penahanan dari jenis yang satu ke jenis penahanan yang lainnya.

Penjatuhan hukuman terhadap kasus yang sama namun pidananya berbeda (desparitas putusan).

Menetapkan jumlah besar kecilnya uang jaminan dalam prasyarat penangguhan penahanan.

Menilai keabsahan akan suatu alat bukti. Dan sebagainya.

Hakim memutus melampaui tuntutan jaksa

Lembaga peradilan di Indonesia setelah melaksanakan tugas dan wewenangnya sesuai Undang- 
Undang No. 8 Tahun 1981 di bidang penegakan proses peradilan pidana tampaknya aspek pengawasan baik internal eksternal, vertikalhorizontal masih sangat lemah, hal ini mengakibatkan proses penegakan peradilan pidana (criminal justice system) belum menghasilkan tujuan yang diharapkan.

Terutama kontrol internal dari lembaga peradilan sendiri tidak jelas, seperti lembaga tertinggi yudisiil Indonesia (MA) tidak jelas siapa yang mengawasi kinerjanya. Pengawasan yang sifatnya eksternal di Indonesia baru muncul dan sedang berkembang mulai saat awal rezim reformasi tahun 1998, seperti lahirnya LSM (Lembaga Swadaya Masyarakat), ICW, MAPPI dan lain-lain), inipun belum menunjukkan hasil yang signifikan karena masih sulitnya menembus informasi di setiap institusi/instansi yang terlibat di dalamnya, yang masih terpola secara birokratisasi dengan dalih rahasia negara dan lain-lain sebagai alasan pembenar semu untuk menutupi penyimpangan yang ada di masing-masing institusinya.

\section{PENUTUP}

\subsection{Simpulan}

Setelah dikaji independesi lembaga peradilan dari perspektif tataran teoritik dihubungkan dengan pengamatan dunia praktisinya dalam lingkup sistem peradilan pidana (criminal justice system) dengan mengambil perbandingan antara sistem hukum Amerika dengan sistem hukum peradilan Indonesia, maka dapat disimpulkan hal-hal seperti berikut :

1. Kinerja pengadilan di Indonesia belum layaknya berperan sebagai sebuah sistem (a true system of justice), sebagai salah satu sub sistem dari komponen sistem dalam bekerjanya sebagai administrator pelaksanaan peradilan pidana (CJS) dengan sub sistem lainnya (polisi, kejaksaan) tampak baru hanya sebatas sebagai jaringan kerja (network)

Karena masing-masing sub sistem sebagai komponen pelaksana administrasi peradilan masih bekerja sendiri-sendiri, tidak memiliki tujuan yang sama. Sistem peradilan pidana Indonesia dinyatakan sebagai model penegakan hukum kita dilakukan secara bersama-sama oleh aparat terkait, arti terpadu disini belum menunjukkan arti sebagai sebuah sistem, baru hanya sebatas interkoneksi (hubungan secara formal), karena kalau kita lihat KUHAP, tidak ada mengatur soal sanksi bila satu komponen tidak bekerja sesuai yang diharuskan.

2. Batas-batas kebebasan yang diberikan kepada institusi pengadilan (termasuk hakim) di Indonesia belum jelas bahkan sudah terpola pemberian kebebasan (diskresi) baik oleh 
hukum pidana materiil (KUHP) sendiri maupun KUHAP, sehingga kewenangan diskresi pengadilan (hakim) di Indonesia cukup luas.

Ada beberapa hal sebagai kendala dalam bekerjanya komponen sub-sub sistem selaku penyelenggara pelaksanaan peradilan pidana (criminaljustice system) seperti tidak adanya tujuan yang sama diantara subsub komponen, kurangnya sarana prasarana penunjang untuk bekerjanya sebuah sistem, tidak dimilikinya keahlian karena kurangnya pelatihan (training) yang dilakukan kepada para administrator peradilan, dan yang terakhir lemahnya pengawasan (kontrol) baik intern-ekstern maupun vertikal-horizontal kepada institusi, personal setiap administrator yang terlibat dalam lingkup kerja sistem peradilan pidana (criminal justice system) sehingga semua ini membawa lemahnya penegakan hukum yang diharapkan dan kacaunya sistem peradilan pidana yang semestinya menjadi harapan setiap pencari keadilan dan semua pihak yang mendambakan keadilan.

Namun harapan tetap menjadi harapan belaka, demi untuk tercapainya keadilan, kemanfaatan dan kapastian hukum oleh semua pencari keadilan.

\subsection{Saran}

1. Hendaknya perlu ada keseragaman pemahaman tujuan dari semua komponen sistem peradilan pidana di negara ini. Semua penegak hukum bekerja guna tercapainya sasaran tujuan dari kinerja sistem (Peradilan Pidana Terpadu) dalam arti sistem yang sesungguhnya ( $a$ system as true system), yakni untuk memerangi kejahatan, resosialisasi dan rehabilitasi pelaku.

2. Hendaknya perlu diciptakan undang-undang pengawasan peradilan dengan wadah terpadu bagi Peradilan Republik Indonesia untuk mengawasi jalannya peradilan selaku aparat pengawas tertinggi terhadap semua komponen sistem Peradilan Pidana Terpadu (Polisi, Jaksa, Hakim Lembaga Pemasyarakatan) dan Advokat untuk tercapainya peradilan yang bersih dan berwibawa terbebas dari mafia praktik peradilan.

\section{DAFTAR PUSTAKA}

Abadinsky Howard, 1984, Discretionary Justice An Introduction to Discretion in Criminal Justice, Charles C. Thomas Publisher, Spring FieldIllionis, USA.

Artha, I Gede, 2012, Kebijakan Formulatif Upaya Hukum Terhadap Putusan Bebas 
Bagi Penuntut Umum Dalam

Perspektif Sistem Peradilan

Pidana Indonesia (Disertasi),

Unibraw, Malang

Black, HC, 2000, (Dalam :Batas

Kebebasan

Kekuasaan

Kehakiman oleh M. Pasek

Diantha, Kertha Patrika Majalah

llmu Hukum FH Unud, No : 75

Tahun XXV.

Harkristuti Harkrisnowo, 2002, Sistem

Peradilan Pidana Terpadu

(Integrated Criminal Justice

System), sebuah Perspektif-

Newsletter-KHN

(Komisi

Hukum Nasional Republik

Indonesia, Edisi Mei.

Kaplan,

Benyamin,

1996,

Pemeriksaan Dengan Devvan

Juri (Terjemahan oleh : Gregory

Churchil atau Talks on American

Law),

(Ceramah-ceramah

Tentang Hukum Amerika), PT.

Tata Nusa, Jakarta.

Packer, H.L. 1968, The Limits of The

Criminal Sanction, Stanford

University Press, California.

Peak,K.J,1995,Justice Administration, Police, Courts, and Corrections Management, Department.of Criminal Justice, University of Nevada, Reno, Prentice Hall Englewood, New Jersy.

Reid, Sue Titus, 1987, Criminal Justice Procedures and Issus, University of Tulsa, West Publishing Company, USA.

Romly Atmasasmita, 1996, Sistem Peradilan Pidana
Perspektif Eksistensialisme

dan Abolisionisme. (Dalam

Mirjan Damaska), Bina Cipta, Bandung.

Soerjono Soekanto, Sri Mamudji, 2001, Penelitian Hukum Normatif, PT. Raja Grafindo Persada, Jakarta

Undang-Undang No. 48 Tahun 2009 tentang Kekuasaan Kehakiman.

Undang-Undang No. 8 Tahun 1981 tentang Kitab UndangUndang Hukum Acara Pidana (KUHAP).

Undang-Undang No. 18 Tahun 2003 tentang Advokat

Undang-Undang No. 12 Tahun 1995 tentang Lembaga Pemasyarakatan

Undang-Undang No. 49 Tahun 2009 tentang Peradilan Umum

Undang-Undang No. 3 Tahun 2009 tentang Mahkamah Agung. 